\title{
Iron Homeostasis and Diabetes Risk
}

\author{
Surapon Tangvarasittichai* \\ Department of Medical Technology, Naresuan University, Thailand
}

Submission: January 27, 2018; Published: July 05, 2018

*Corresponding author: Surapon Tangvarasittichai, Chronic Diseases Research Unit, Department of Medical Technology, Faculty of Allied Health Sciences, Naresuan University, Phitsanulok 65000, Thailand, Tel: +66896388382; Fax: +6655966300; Email: surapon14t@yahoo.com

\begin{abstract}
Iron binds to protein in the form of heme and functions as co-factor of enzymes that mediate redox reactions for energy production and intermediate of metabolism. Individual iron status is reflected as the combination of nutritional and pathological diseases. Iron overload (IO) and iron deficiency anemia (IDA) are the risk factor for diabetes. The association of iron and diabetes was investigated in $\beta$-thalassemia patients, in high dietary iron levels, and in iron deficiency anemia were also associated with diabetes risk. IO and IDA play the major role of oxidative stress and inflammation, mediated insulin resistance and $\beta$-cell dysfunction to causal diabetes. The underlying mechanisms mediated of these effects still waiting for searching.
\end{abstract}

Keywords: Iron overload; Iron deficiency anemia; Oxidative stress; Diabetes mellitus

Abbreviations: DMT-1: Divalent Metal Transporter 1; Hmox: Hemeoxygenase; DCTB: Duodenal Cytochrome b; HEPH: Hephaestin; FPN: Ferroportin; Tf: Transferrin; TfR1: Transferrin Receptor 1; TfR2: Transferrin Receptor 2; HJV: Hemojuvelin; BMP: Bone Morphogenic Protein; SMAD: Human Homolog of Drosophila Mad

\section{Introduction}

Iron is one of the major functional compo $\neg$ nents in many proteins, involved in the wide range of vital biochemical functions. Iron is also functions as co-factor of enzymes that mediate redox reactions for energy production and intermediate of metabolisms. The major iron metabolism is on the traditional areas of erythropoiesis and nutrition. Iron is also represent as a major role in oncology, neurological, cardiology, infectious diseases and many pathology diseases. Individual iron status is reflected as the combination of pathological diseases, nutritional, environmental and genetic factors. Iron may directly bind to protein (or as the iron containing) in the form of heme or ironsulfur clusters. Normal iron levels ensure ready availability for optimal metabolic activity to maintain the normal physiological function and immune system. For understanding the degree of the changing of normal iron status can predispose to the wide variety of disorders. Transition heavy metals including ferrous iron $\left(\mathrm{Fe}^{2+}\right)$ and copper $\left(\mathrm{Cu}^{+}\right)$can increase oxidative stress, especially in $\mathrm{Fe}^{2+}$ may cause autooxidation to generate superoxide $\left(\mathrm{O}^{2 \bullet}\right)$ and/or to generate hydroxyl radical $(\mathrm{OH} \bullet)$ by interaction with hydrogen peroxide $\left(\mathrm{H}_{2} \mathrm{O}_{2}\right)$ via the Fenton and Harber Weiss reactions [1]. Major cellular oxidative stress came from mitochondrial respiration. Heart, brain, kidney, liver and skeletal muscle are the major effective organs for oxygen consumption. These organs converted oxygen to $\mathrm{O}_{2}{ }^{--}[2]$.
Electron transport chain in mitochondrial has also been sourced to $\mathrm{O}_{2}{ }^{-}[3]$.

Many research studies demonstrated the association of increased oxidative stress with insulin resistance, insulin signals dysfunction and adipocytokines dysregulation [4,5]. Type 2 diabetes mellitus is a common and well described in terms of insulin resistance and $\beta$-cell dysfunction. Recent studies have been demonstrated the abnormalities of insulin signaling and insulin secretion caused from the activation of stress pathways, mitochondrial dysfunction, hepatic fuel homeostasis, and central nervous system dysregulation [6-9]. Obesity is the well accepted predictor for the disease. Therefore, it is well accepted that the most reliable predictor for the disease is obesity. The attention has also been paid to the nutrients and the nutrient-sensing pathways in the conditions of chronic caloric excess. Most of the interest role of nutrients in diabetes risk is attended on macronutrients while a micronutrient is iron closely associated with diabetes risk. Body iron store elevation has been linked to factors of the metabolic syndrome, obesity, dyslipidemia, hypertension, hyperglycemia and diabetes [10-14]. The association between iron and diabetes were demonstrated that the mean $( \pm$ SD) concentration of ferritin was significantly higher than controls $[109( \pm 105)$ vs $71.5( \pm 68.7) \mathrm{ng} / \mathrm{mL} ; \mathrm{P}<0.001]$ and the mean $( \pm S D)$ ratio of transferrin receptors to ferritin 
was significantly lower $[102( \pm 205)$ vs $141( \pm 340)$; $\mathrm{P}=0.01]$, respectively for developing diabetes [15]. Iron deficiency is also associated with obesity, diabetes risk and also with diabetes risk for anemia. In this review will briefly summarize the homeostasis of iron, iron and oxidative stress, the association of excess iron with increased diabetes risk, the effects of iron on insulin resistance, iron deficiency and diabetes risk, and anemia in diabetes patients.

\section{Iron and oxidative stress}

In eukaryotic cells, reactive oxygen species (ROS) was produced as the normal aerobic physiological metabolism [16]. ROS levels were counter-balanced with the antioxidants in the normal physiological conditions. ROS was defined as any chemicals those have reactive activities to accommodate or donate electrons (e-) to the biological molecules. ROS also include instability radicals arise from an unpaired e- [17].

$$
\begin{aligned}
& \mathrm{O}_{2}+\mathrm{e}+\mathrm{H}+\rightarrow \mathrm{HO}_{2} \bullet(\text { hydroperoxyl radical) } \\
& \mathrm{HO}_{2} \bullet \rightarrow \mathrm{H}++\mathrm{O}_{2} \bullet-(\text { superoxide radical) } \\
& \mathrm{O}_{2} \bullet+2 \mathrm{H}^{+}+\mathrm{e} \rightarrow \mathrm{H}_{2} \mathrm{O}_{2} \text { (hydrogen peroxide) } \\
& \mathrm{H}_{2} \mathrm{O}_{2}+\mathrm{e} \rightarrow \mathrm{OH}^{-}+\mathrm{OH} \bullet \text { (hydroxyl radical) }
\end{aligned}
$$

However, at the normal physiological state in the living systems, oxygen consumption always produce oxygenderived free radicals including $\mathrm{O}_{2}{ }^{\bullet}, \mathrm{OH} \bullet$, alkoxylradical $(\mathrm{RO} \bullet$ ), peroxylradical $\left(\mathrm{RO}_{2} \bullet\right.$ ), peroxynitrite (ONOO-) and oxygen derived non-radicals such as $\mathrm{H}_{2} \mathrm{O}_{2}$, hypochlorous acid ( $\mathrm{HOCl}$ ) and hypobromous acid ( $\mathrm{HOBr}$ ). These reactive molecules (both in free radicals and non-radicals) were also played an adverse role in the physiological systems as oxidative stress mediated cellular damages [18]. In normal condition, neutralization of ROS productions by cellular antioxidant defense mechanisms was determined as the physiological condition and do not causes any oxidative damage [19]. In the imbalance condition, over ROS production and reduction of the antioxidant defense mechanisms in the living systems can caused cellular dysfunction and damage [20]. ROS may also be derived from the physiological and biochemical reactions to generate ROS as byproducts or end products. In mitochondrial, electron transport chain, peroxisomes and cytochrome P450 system are the major sources of ROS production (involves in $\mathrm{O}_{2}{ }^{--}$production) [21]. Moreover, various enzymes in physiological condition can be accelerated ROS production including cyclooxygenases [22,23], xanthine oxidase [24], uncoupled nitric oxide synthases (NOS) [25-27] and NADPH oxidases [28]. Heavy metals (Fe, Cd, Pb, $\mathrm{Hg}$ ) as the toxic substances [29-32], acrolein, chloroform, carbon tetrachloride [33], tertiary butyl hydroperoxide [3437], environmental pollutants (oxides of nitrogen, $\mathrm{SO}_{2}, \mathrm{CO}_{2}$ ), xenobiotics, UV irradiation and the other factors induce ROS overproduction. The transition heavy metals, iron $\left(\mathrm{Fe}^{2+}\right)$ and copper $\left(\mathrm{Cu}^{+}\right)$can be produced reactive radicals (oxidative stress), especially in $\mathrm{Fe}^{2+}$ may cause autooxidation to cause $\mathrm{O}_{2}{ }^{\text {. }}$ generation and/or interaction with $\mathrm{H}_{2} \mathrm{O}_{2}$ can generate $\mathrm{OH} \bullet$ via the Fenton and Harber Weiss reactions [1]. Fenton reaction may also be causes lipid peroxides generation and propagation [38].

Auto oxidation of $\mathrm{Fe}^{2+}: \mathrm{Fe}^{2+}+\mathrm{O}_{2} \rightarrow \mathrm{Fe}^{3+}+\mathrm{O}_{2} \bullet$

Fenton reaction: $\mathrm{H}_{2} \mathrm{O}_{2}+\mathrm{Fe}^{2+} \rightarrow \mathrm{Fe}^{3+}+\mathrm{OH}^{-}+\mathrm{OH} \bullet$

$\mathrm{Fe}$

Haber-Weiss reaction: $\mathrm{H}_{2} \mathrm{O}_{2}+\mathrm{O}_{2}{ }^{--} \rightarrow \mathrm{O}_{2}+\mathrm{OH}-+\mathrm{OH} \bullet$

Iron demonstrated the reversibly oxidized and reduced property, it plays the importance role in the pathophysiology of disease because of the generation of powerful oxidant species via the Fenton and Harber Weiss reactions [39]. Because iron participates in the ROS formation then organisms take great care of iron handling. Indeed, iron sequestration in transport and storage proteins may contribute to antioxidant defenses mechanism.

\section{Iron homeostasis}

Iron is a major cofactor for energy generation of oxidation and electron transport reactions. Iron also cause increased oxidative damage when it dys-regulated, sequestered or excess. Thus, extensive mechanisms are importance for control the iron homeostasis in the body. Iron and physiological metabolism connections are well established, even in lower organisms. Iron in mammalian organisms is recycled in about rate of $20-25 \mathrm{mg} /$ day through the major site, the erythroid pool as macrophages endocytose of the senescent erythrocytes. Approximately 5\%$10 \%$ of iron amount per day was taken up through the intestine. In mammals, do not have mechanisms for the excess iron excretion to regulate iron balance. In equilibrium, losses may via the death of the intestinal epithelium and other cells death, and the biliary excretion may balance with the intestinal uptake. When exceeds uptake to cause excessive iron sequestered intracellular. Because the disposal of excess iron in humans was the slow process, but the iron uptake from the intestine was highly regulated.

At duodenumenterocytes, enzyme ferrireductase duodenal cytochrome $b$ (DCTB) reduces ferric iron $\left(\mathrm{Fe}^{3+}\right)$ from transferrin to ferrous iron $\left(\mathrm{Fe}^{2+}\right) . \mathrm{Fe}^{2+}$ ions enter to the cytosol through the divalent metal-ion transporter 1 (DMT1 or SLC11A2). Zip14, a non-transferrin-bound iron transportercan also enter the cytosol through DMT1 $[40,41] . \mathrm{Fe}^{2+}$-DMT1pass through the circulation via iron export channel, ferroportin (FPN or SLC40A1). The $\mathrm{Fe}^{2+}$ is oxidized to $\mathrm{Fe}^{3+}$ by hephaestin (HEPH) and then, binds to transferrin in the circulation. This transferrin can be taken into cells via transferrin receptors (TfRs), TfR1 was found and mediated iron uptake in most cells. The soluble-transferrin receptor, a soluble form of the transferrin receptor bound with transferrin, it level is a sensitive indicator for functional iron deficiency [42]. Transferrin saturation is the mechanisms 


\section{Current Research in Diabetes \& Obesity Journal}

to play a major role of iron overload conditions. Most of irons were used for heme and iron-sulfur cluster synthesis in mitochondria. Iron levels in cytosol were autoregulated via the binding with iron regulatory proteins (IRPs). IRPs were released from the iron-responsive element (IRE) of the TfR 1 messenger RNA (mRNA) at the 30 untranslated region (UTR) and at the 50UTR of the ferritin mRNA and at the UTRs of mRNAs of the other iron-regulated proteins when excess iron were occurred. Resulting in decreased TfR mRNA stability, further decreased iron uptake, increased ferritin translation and sequestering iron inside the cell. Then, increased ferritin level is translated to the largely free iron as a marker of tissue iron stores. Transferrinbound iron can also interacts with the hepatocyte TfR2 and HFE protein on the surface of hepatocytes [43] via the signaling process including with hemojuvelin (HJV), bone morphogenic protein 6 (BMP6) [44,45] and the SMAD (human homolog of Drosophila mad) pathway [46] for the stimulation of the hepcidin production. TfR2, HJV, HFE, and hepcidin were involved in human iron homeostasis demonstration in iron overload by human mutations of these proteins.
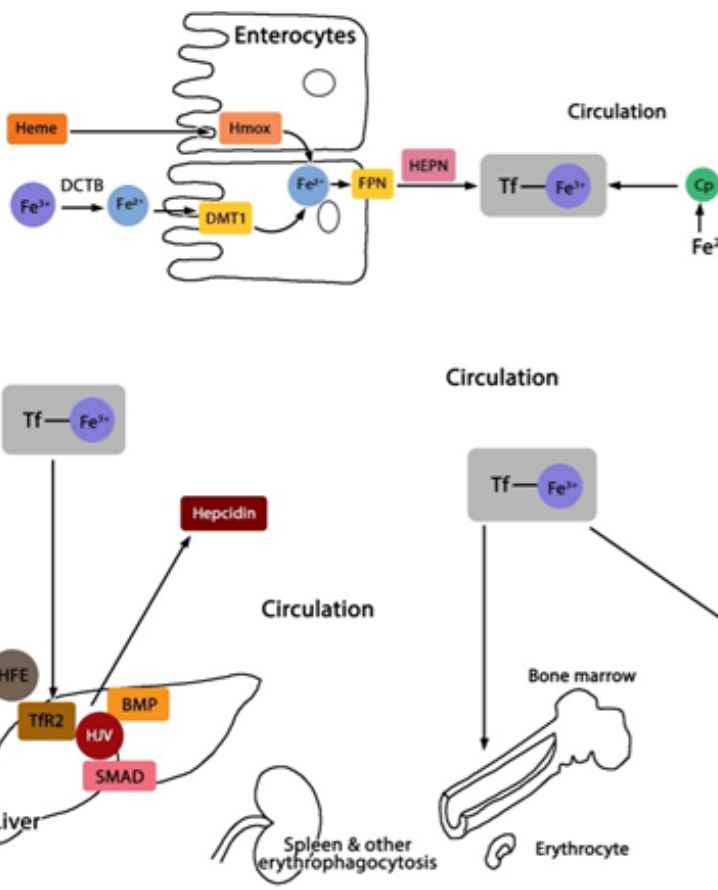

Circulation
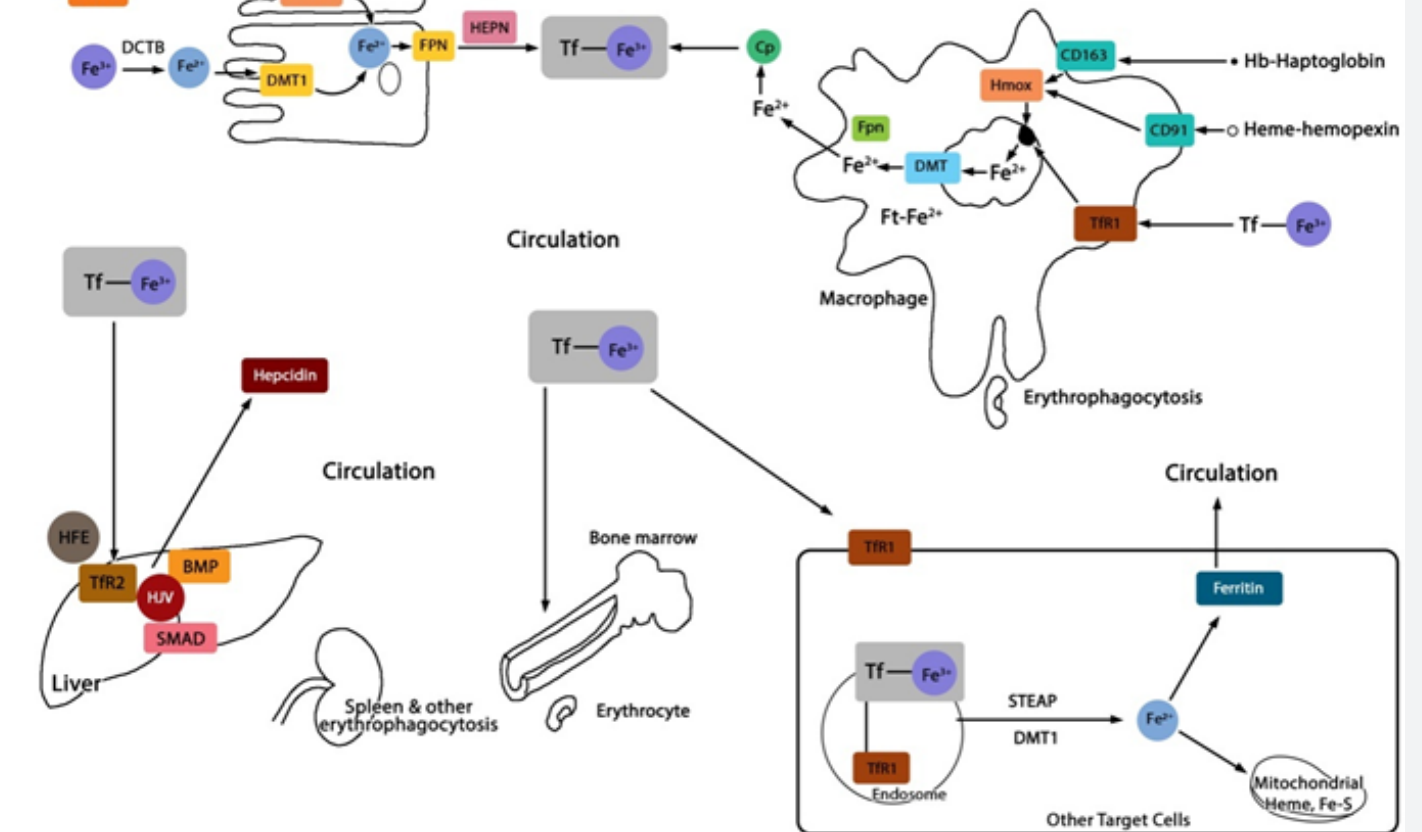

Figure 1: Schematic of iron handling: At duodenum enterocytes, ferric $\left(\mathrm{Fe}^{3+}\right)$ iron is reduced to $\mathrm{Fe}^{2+}$ by $\mathrm{DCTB}$ and enters the cell through the divalent metal-ion transporter 1 (DMT1).

Hepcidin, a 25 amino acid peptide, an acute-phase reactant protein, which is secreted by hepatocytes and acts as a negative feedback regulator of iron absorption, it induces internalization and degradation of intestinal epithelial ferroportin in circulation [47]. Hepcidin also regulates efflux of iron from macrophages, express the high ferroportin levels. The releasing of iron from the enterocyte is the major control point for iron entry into the body. DMT1 is regulated by iron levels, hepcidin-dependent mechanisms and hypoxia-inducible transcription factor (HIF)2a $[48,49]$. Dietary heme is directly absorbed through the enterocyte pathways and using hemeoxygenase (Hmox) iron releasing from heme [50], these were summarized in Figure 1. While dietary heme is absorbed and iron is released by hemeoxygenase (Hmox). Iron exits the enterocyte through the iron export channel ferroportin (FPN) and oxidized by hephaestin (HEPH) to $\mathrm{Fe}^{3+}$ and binds with transferrin (Tf) in circulation. Thereafter, $\mathrm{Tf}-\mathrm{Fe}^{3+}$ transported to bone marrow to produce heme for erythrocyte production. In the spleen, most of the iron was taken up by macrophages via the phagocytosis of senescent erythrocytes and also reabsorbed iron by systemic macrophages with their specific receptors. CD163 binds hemoglobin-haptoglobin complexes, CD91 binds hemehemopexin complexes, and TfR1 binds Tf- $\mathrm{Fe}^{3+}$. Once bound with their receptor, iron is endocytosed and $\mathrm{pH}$ changed induces iron reduction and release into the cytoplasm. Iron is released from cells via Fpn 1 and bound with Tf. This $\mathrm{Tf}_{-} \mathrm{Fe}^{3+}$ can bind to transferrin receptors 1 and 2 (TfR 1 and TfR2) on the surface of target cells. In most cells, after $\mathrm{Tf}_{-}-\mathrm{Fe}^{3+}$ bound to TfR 1 and acidification in endosome, iron was released and reduced by STEAP and bind to DMT1 enters the cytosol, where it is used for heme or Fe-S cluster synthesis in the mitochondrion. In excess, were sequestered by the form of ferritin into the circulation. Ferritin level serves as a marker for tissue iron stores. In the liver, Tf- $\mathrm{Fe}^{3+}$ binds TfR2 and the protein HFE, GPI anchored protein 


\section{Current Research in Diabetes \& Obesity Journal}

hemojuvelin (HJV), bone morphogenic proteins (BMP) and the SMAD play the concert signal transduction pathway of hepcidin production. Hepcidin induces internalization and degradation of FPN, thus completing a negative feedback regulatory loop.

For the evaluation of the effects of iron on metabolism, the important consideration is the wide normal range of serum ferritin in humans, 30-300 $\mathrm{ng} / \mathrm{ml}$ in men and $15-200 \mathrm{ng} / \mathrm{ml}$ in women [51,52]. These serum ferritin levels in humans have a 10 -fold of normal variation, these may not be an ideal normal value. Because of the extensive regulation of iron uptake, the dietary iron excess can achieve tissue iron levels higher than the necessary levels to maintain physiological erythropoiesis and metabolic function. For example, in general commercial rodent chows, there are the large variations in iron content a factor greater than ten times. The bioavailability of iron is considered more important than the absolute levels, many chows deliver higher iron contents that are consumed by mice living in the wild necessary to maintain normal breeding and blood hemoglobin concentrations. The same results of the many humans diets. Then, within the boundaries of tissue iron levels defined by overt iron deficiency and pathological of overload, the broad range of normal iron levels may include the levels that confer health risks which unaware.

In circulation, there are three main iron forms: $\mathrm{Fe}^{3+}$ bound to transferrin (Tf), hemoglobin bound to haptoglobin and heme bound to hemopexin. In bone-marrow erythroblasts, iron is used for hemoglobin formation in the nascent erythrocytes. Senescent erythrocytes are phagocytosed by splenic macrophages. The iron is recycled back for the erythroblasts formation, the recycled iron by macrophages is a 10 -fold higher than the absorbed iron from duodenum [53]. Macrophages are responsible for cycling iron in many tissues such as spleen, bone marrow, liver and lung [54-56]. Macrophages also express the three types of iron receptors also present in serum including(i) transferrin receptor (TfR1) binds to $\mathrm{Fe}^{3+}$-Tf, (ii) cluster of differentiation 91 (CD91) binds to heme-hemopexin, and (iii) CD163 binds to haptoglobinhemoglobin ( $\mathrm{Hp}-\mathrm{Hb})$. These were also demonstrated in.

Iron homeostatic pathways are tightly linked to inflammation. This inflammation causes from a significant hepcidinupregulation, via interleukin-6 (IL-6), and also results in increases serum ferritin levels [57]. Inflammation can cause the suppression of intestinal iron uptake, it has been hypothesized to be related with the beneficial effect of sequestering iron from invading microbes. This may elucidate the link of iron to diabetes that links to inflammation [58]. The complexity of the association among diabetes, inflammation and ferritin reflect the excess iron stores cause diabetes and reflect inflammation causes diabetes or both. Furthermore, if iron causes diabetes, the ability of the importance mechanisms could be cause oxidant stress and may also be linked to inflammation. This evidence suggests that iron overload can be cause diabetes.

\section{Role of iron in the induction of diabetes}

Evidence of the systemic iron overload in classic hereditary hemochromatosis $(\mathrm{HH})$ was frequency increased diabetes mellitus. This evidence demonstrated that iron could contribute to abnormal glucose metabolism. In the genetic disorders of iron metabolism demonstrated iron overload resulting in the increased of type 2 diabetes. The role of iron in the pathogenesis of diabetes is uncertain but increased of type 2 diabetes in diverse causes of iron overload and improvement in diabetes with reduction in iron load by using iron chelation therapy. Recent studies demonstrated the association between increased dietary iron intake (eating red meat) and increased body iron stores with development of diabetes. These studies suggested frequent blood donation and decreased iron stores improve insulin sensitivity and insulin secretion $[59,60]$. Although the exact mechanism of iron-induced diabetes is unclear, it is likely to mediate by four key mechanisms: (i) oxidative stress and inflammation, (ii) insulin resistance, (iii) insulin deficiency and (iv) hepatic dysfunction. For the understanding of the pathogenesis of iron-induced diabetes pathways was derived from the animal models of hemochromatosis. In mouse model characterize of iron excess and oxidative stress mediate apoptosis of pancreatic islets resulting in decrease capacity of insulin secretion [61]. Pancreatic islets were caused oxidative damage, and may cause dysregulation of mitochondrial metabolism of glucose for glucose-induced insulin secretion and increased antioxidant defense using and low expression of the antioxidant defense system [62]. Increased expression of the divalent metal transporter proteins may addition with more accumulation of iron than other cells and potentiates with increased risk from iron catalyzed oxidative stress [63]. In study on transfusiondependent $\beta$-thalassemic/HbE patient demonstrated the association of iron over load, increased oxidative stress, hepatic damage, dyslipidemia [64].

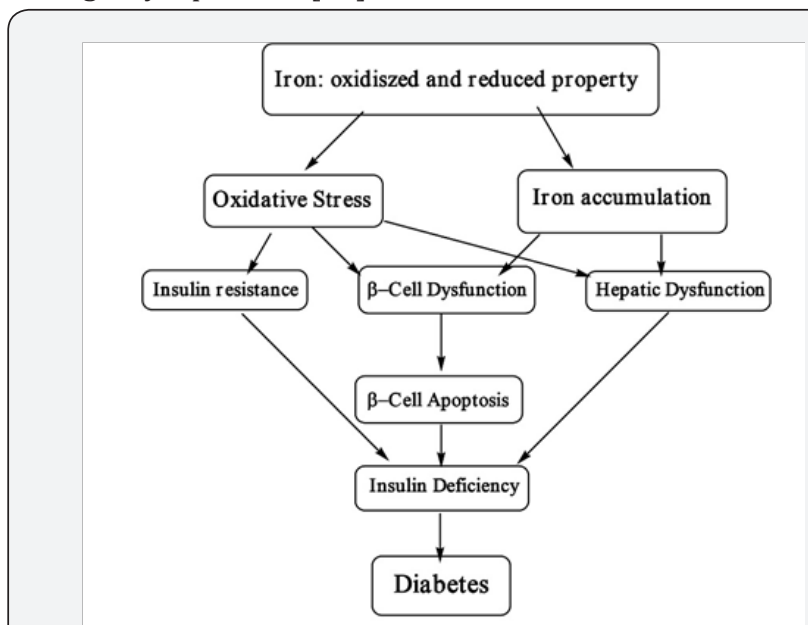

Figure 2: Schematic pathway of the iron induces oxidative stress and diabetes pathogenesis.

Oxidative stress plays an important role of the numerous pathologies in cardiovascular diseases, cancer and degenerative 
disease [65]. Oxidative stress is the deleterious factor leading to insulin resistance, $\beta$-cell dysfunction, impaired glucose tolerance, and type 2 diabetes mellitus $[66,67]$. McClain et al. [68] examined the high prevalence of abnormal glucose homeostasis in individuals with hemochromatosis by using glucose tolerance tests. They found that these hemochromatosis patients demonstrated not only impaired insulin secretion but also insulin resistance. Insulin resistance and impaired insulin secretion may cause from iron overload or through hepatic dysfunction [69]. The schematic of these processing were summarized in Figure 2.

\section{Transfusional iron overload and diabetes risk}

The most common acquired iron overload is typically found in transfusion-dependent $\beta$-thalassemia. Because of the ineffective erythropoiesis, decreased or impaired $\beta$-globin biosynthesis in $\beta$-thalassemia plays a crucial role in oxidative stress production [70]. Moreover, the heme-iron can free to generate $\mathrm{H}_{2} \mathrm{O}_{2}$ via the Fenton reaction. Anemia and excessive ROS are the hallmark of thalassemia [71]. Indeed, ROS and peroxidative tissue injury in these patients represent an unavoidable complication accelerated multi-organ damage, especially in excess iron accumulationin organs, such as liver, pituitary gland, pancreas and heart. Increased oxidative stress is the deleterious factor leading to insulin resistance, $\beta$-cell dysfunction, impaired glucose tolerance, and type 2 diabetes mellitus [66,67]. Many studies demonstrated impaired glucose tolerance and its progression towards overt diabetes mellitus which depended on the severity and duration of iron overload in $\beta$-TM patients [72-75]. These patients are often detected as impaired glucose tolerance in the second decade of life. In the study of Chern et al., they found $19.5 \%$ with diabetes and $8.5 \%$ with impaired glucose tolerance of the 80 transfusion-dependent $\beta$-thalassemia patients and demonstrated high serum ferritin and hepatitis $\mathrm{C}(\mathrm{HCV})$ infection as the risk factors for impaired glucose tolerance and type 2 diabetes mellitus [75]. While insulin deficiency may cause from iron accommodation in the interstitial pancreatic cells caused excess collagen deposition, obstructive the microcirculation and insulin resistance [76,77]. Glucose tolerance up to one-third of these patients was improved by intravenous or oral chelation treatment, these suggested the causal role of iron $[78,79]$. Our recent study demonstrated that transfusion-dependent $\beta$-thalassemia patients associated with iron overload, oxidative stress, and hyperinsulinemia or insulin resistance [80]. Loebstein et al. [81] demonstrated the direct role of iron-derived free radicals mediating organ damage of in transfusion-dependent diabetes patients with increased lipid peroxidation accelerated diabetic nephropathy onset.

\section{Iron deficiency and diabetes risk}

Approximately $75 \%$ of iron in human body is associated with hemoglobin, iron protein containing is responsible for oxygen transport of red blood cell (RBC). Anemia is a pathologic condition of decrease mass or amount of hemoglobin in red blood cell. Iron deficiency anemia (IDA) is the most common nutritional problem about 30 percent of people throughout the world [82]. Iron deficiency limits the synthesis of heme (a prosthetic group of hemoglobin) in the body, limits of hemoglobin synthesis and decreases the RBC production resulting in anemia. These are also affected the cellular energy metabolism of oxygen dependent. Iron deficiency also affects all of the $\mathrm{Fe}^{2+}$ containing proteins production such as myoglobin, catalase (CAT), peroxidase and cytochromes [83]. Anemia has a wide range of clinical consequences, especially in severe iron deficiency is a decrease RBCs- life span in circulation, it exacerbates the anemic condition [84-89]. The ID-RBCs were increased membrane stiffness and decrease in deformability, these may accelerated macrophages recognition [90-92], which decreases the ability of ID-RBCs to pass through the spleen without being removed. The deformability decreasing in IDRBCs can increase cytosolic calcium levels which increase the ID-RBCs membrane stiffness to attribute oxidative stress [9395]. Recent studies demonstrated the ID can accelerate RBCs eryptosis by increased the phosphatidylserine residue on the outer surface membrane for macrophages recognition resulting in the removed RBCs from circulation $[89,93]$. However, ROS of RBCs are one of the importance factors of anemia. ROS elevation in RBCs can occur either by activation of ROS production or by suppression of antioxidant or redox system. When RBCs cause an excessive ROS production, oxidative stress develops. Generally, $50 \%$ of anemia cause from iron deficien $\neg$ cy. More recent studies demonstrated that reduced iron stores were associated with increased glycation (hemoglobin A1C; HbA1c) [96-98].

Animal models: In ID-animal models were demonstrated glucose and lipid metabolism alıterations. ID-animals present signs of the metabolic homeostasis disruption such as insulin signaling alterations evidenced of hyperinsulinemia, hyperglycemia and hyperlipidemia. Decreasing in oxidative capacity causes a shift in fuel utilization from fat to glucose [99-102]. These signs appeared as response grading associated with the hemoglobin reduction. However, in the non-severe hemoglobin reductions are not correlated with hyperglycemia and hyperlipidemia. These findings may suggest that these may have a certain threshold exists in order to develop these potentially negative meta-bolic consequences [103-106]. However, other studies, in the moderate in $\neg$ duction of iron deficiency in ro $\neg$ dents are sufficient to disrupt normal metabolic homeostasis, to cause glucose and insulin elevations in both steady-state levels with the basal diet for-mulation in the IDanimals. High cortisol secretion, the secondary of the stress of anemia status, is not responsible for the hyperglycemia, while hyperglycemia was associated with de $\neg$ crease cortisol levels in the ID-animals [104-109].

The other studies demonstrated the hepatic genes expression was involved in stabilized glucose homeosta $\urcorner$ sis during ID. 
These studies demonstrated ID rats in each group had significant alterations in genes expression of glucose metabolism [110]. These gene expressions are also include those genes involve $d$ in glycolysis and gluconeogenesis of metabolic pathways. The increasing of glucokinase (Gck) gene expression in ID-animals is relative increase insulin levels in cir $\urcorner$ culation. This insulin is the inducer of the hepatic Gck mRNA ex-pression. Increased Gck expression has been shown increased on the glucose levels as a metabolic substrate, to increase glucose phosphorylation rate in the liver, responsible for blood glucose elevations. Furthermore, Gck may involve in the multiple pathways such as glycogen synthesis, glycolysis, and de novo lipogenesis which may explain the enhancing of the glucose utilization and hyperlipidemia in the responsible to dietary ID-animals [110-116]. In the studies of metabolic gene expression alterations indicate an impaired hepatic insulin response in ID-animals, exhibited as insulin resistance. In this model, rapamycin complex 1 act as target of insulin to cause lipogenesis activation via the sterol regulaᄀtory element-binding protein-1c, while diminished insulin-induced phosphorylation of forkhead box protein 01 the transcription factor, inappropriate the glu $\neg$ coneogenic gene expression. Thus, mixed insulin resistance demonstrates as the candi-date mechanism responsible for these hyperglycemia and hyperlipidemia in ID-animals [117-122].

Human studies: Iron deficiency, the most common mi $\neg$ cronutrient deficiency remains in the world. General symptoms of IDApatients such as weakness, fatigue, impaired immune function, and reduced cognitive function, especially in children. Serum level of fer $\neg$ ritin was reflected the accurate iron status in the body. Many studies demonstrated the association of the reduction of iron stores with hemoglobin A1C (HbA1c) elevation. Many studies demonstrated the association of ID/IDA with the alteration of blood glucose, HbA1c and insulin levels $[99,123,124]$.

\section{Non-diabetic patients with IDA}

In the cor $\neg$ rection of IDA study, 54 non-diabetic premenopausal women with IDA were corrected the $\mathrm{Hb}$ concentration from of $9.9 \pm 1.8 \mathrm{~g} / \mathrm{dL}$ to $13.1 \pm 1 \mathrm{~g} / \mathrm{dL}$ demonstrated fasting insulin reduction, insulin resistance and also found the positive correlation of fasting insulin levels with hemo $\operatorname{colobin}$ levels after treatment [125]. The non-diabetic patients with IDA patients demonstrated the signifi $\neg$ cant reduction of HbA1c values after iron treatment [126,123]. While the study of Gram Hansen et al. [127] demonstrated normal HbA1c levels in IDApatients were dropped to subnormal levels after iron treatment. Many research studies were also demonstrated the association of HbA1C reduction with erythrocyte indices and iron metabolic indices after iron treatment $[97,98,128,129]$.

\section{IDA and type 2 DM patients}

Many research studies demonstrated the association between IDA (patients with $\mathrm{Hb}:=9.4 \pm 1.3 \mathrm{~g} / \mathrm{dL}$ ) with $\mathrm{HbA} 1 \mathrm{c}$ levels, especially in dia betic women having FPG between $100-126 \mathrm{mg} / \mathrm{dl}$, or diabetic chronic kidney disease, or diabetic pregnancy with IDA $(\mathrm{Hb} \leq 10.5 \mathrm{~g} / \mathrm{dl})$, which was reduced following iron treatment and increased Hb level [96,130-133]. Anemia in diabetic patient is always present as a biomarker for disease progression, the co-morbidities develop $\neg$ ment and quality of life. Hemoglobin (Hb) levels reduction may indicate increased risk of the renal disease progression. In type 1 diabetes mellitus, anemia is associated with micro- and macrovascular complications, the role of anemia may involve in the progression of these complications [133-136]. From the direct relationship of anemia and diabetic kidney disease, type 2 diabetes patients had reduced $\mathrm{Hb}$ levels to identify patients with increased risk for renal disease progression [132].

Anemia may play importance role in the mitogenic and fibrogenic process in kidney and the heart, these may associated with growth factors, hormones, and vasoactive reagents expressions. Many of these agents were involved in diabetic mi $\neg$ crovascular disease. Because RBCs act as importance antioxidant component in the circulation, thus, IDA patients had increase oxidative stress [132-135]. IDA patients are associated with increased oxidative stress and demonstration of increased triglycerides, decreased high-density lipoproteins (HDL) particles [136] and increased cholesteryl ester transfer protein (CETP) activity. IDA patients demonstrated lower arylester $\neg$ ase activity of paraoxonase-1 (PON-1) after received iron supplementation improved arylesterase activity of PON-1 and decreased malondialdehyde levels [136,137].

\section{Anemia in diabetes patients}

Type 2 diabetes mellitus is associated with increased oxidative stress and inflammation. Increased inflammatory cytokines plays the major role in insulin resistance and cardiovascular diseases risk as the micro- and macrovascular diabetic complication, renal disease and anemia. Interleukin-6 (IL-6) can limit the sensitivity of erythropoietin; an erythroid growth factor and also promotes immature erythrocytes apoptosis. The progression of nephropathy may effect erythropoietin reduction contributing the deterioration to anemia. Thus, diabetic patients with renal disease are at high risk for anemia. Many research studies reported the prevalence of IDA is signifi $\neg$ cant in type 2 diabetes mellitus patients, espe $\neg$ cially with nephropathy [138-142]. The clinical relevance of the effect of iron deficiency on glucose metabolism and HbA1c is still not elucidated. The reduction of iron ab $\neg$ sorption and gastrointestinal bleeding were the diabetic complications caused anemia [96-98].

Metformin, an antidiabetic drug is the most common prescription for diabetic patients. It may cause the adverse effects including diarrhea, dyspepsia, poor appetite, vomiting, lactic acidosis, and metallic taste. Long-term use of metformin may increase vitamin B 12 deficiency that has been indicated as a cause of hemolytic anemia [143]. However, drug-induced 


\section{Current Research in Diabetes \& Obesity Journal}

immunehemolytic anemia (DIHA) can be caused by many different mechanisms. Many drugs bind with proteins on the RBC membrane by covalent bond to cause hemolytic reaction on the presence of the drug and ceases shortly after discontinuation [144]. The DIHA is the immune complex reaction, which antibodies were formed to combine with proteins on RBC membrane and drugs to activate the complement resulting in acute intravascular hemolysis, DIHA may associate with drugindependent antibodies, these antibodies do not need drug to present in vitro reactions (e.g. fludarabine). Drug affects the immune system by causing the RBC autoantibodies production [144]. Although antibodies against the drug cannot be detected, based on the negative Coombs test with complement and no continuous hemolysis after the cessation of metformin, this hemolysis reaction was a drug-dependent reaction. A few cases of metformin-induced hemolysis were reported [143,145148]. The recommendation on drug-induced hemolytic anemia, is to discontinue the potential drug treatment. In severe hemolysis case, may be operated further by RBC transfusion or plasmapheresis or dialysis in patients with renal failure [149].

\section{Conclusion}

Iron demonstrated the reversibly oxidized and reduced property, it play the importance role in the pathophysiology of disease by the generation of powerful oxidant species via the Fenton and Harber Weiss reactions. Oxidative stress is the deleterious factor leading to insulin resistance, $\beta$-cell dysfunction, impaired glucose tolerance, and type 2 diabetes mellitus. Human research and animal experimental studies have established the association of iron stores with diabetes risk. Many research studies suggest the relationship between higher iron and caused diabetes and iron demonstrate the multiplicity of effects in many tissues runs from iron deficiency to iron excess. The phenotypes of iron excess might be particularly prone to increase oxidative stress resulting insulin resistance and $\beta$-cell failure to cause insulin deficiency causing diabetes. Iron deficiency also affects all of the $\mathrm{Fe}^{2+}$ containing proteins production such as myoglobin, catalase (CAT), peroxidase and cytochromes. Oxidative stress elevation in RBCs can occur either by activation of ROS production or by suppression of antioxidant or redox system. ID-subjects present signs of the metabolic homeostasis disruption such as insulin signaling alterations evidenced of hyperinsulinemia, hyperglycemia and hyperlipidemia. These produce the possible of excess iron stores and ID/IDA contributes to cause diabetes. For further research is needed regarding the cut-off point for serum ferritin concentration in diabetes patients, and the affecting of body iron stores to cause insulin resistance, vascular resistance, blood viscosity and oxidative damage.

\section{Acknowledgement}

We sincerely thank all co-workers, technical assistance and Asst. Prof. Dr. Ronald A. Markwardt, Burapha University, for his critical reading and correcting of the manuscript.

\section{Conflict of Interest}

The author has no conflict of interest to report.

\section{References}

1. Rada B, Hably C, Meczner A, Timár C, Lakatos G, et al. (2008) Role of Nox2 in elimination of microorganisms. Semin Immunopathol 30(3): 237-253.

2. Tahara EB, Navarete FD, Kowaltowski AJ (2009) Tissue-, substrateand site-specific characteristics of mitochondrial reactive oxygen species generation. Free Radic Biol Med 46(9): 1283-1297.

3. Richter C (1988) Do mitochondrial DNA fragments promote cancer and aging? FEBS Lett 241(1-2): 1-5.

4. Furukawa S, Fujita T, Shimabukuro M, Iwaki M, Yamada Y, et al. (2004) Increased oxidative stress in obesity and its impact on metabolic syndrome. J Clin Invest 114(12): 1752-1761.

5. Houstis N, Rosen ED, Lander ES (2006) Reactive oxygen species have a causal role in multiple forms of insulin resistance. Nature 440(7086): 944-948.

6. Hotamisligil GS (2003) Inflammatory pathways and insulin action. Int J Obes Relat Metab Disord 27(Suppl 3): S53-S55.

7. Kahn BB (1998) Type 2 diabetes: when insulin secretion fails to compensate for insulin resistance. Cell 92(5): 593-596.

8. Kahn SE (2003) The relative contributions of insulin resistance and beta-cell dysfunction to the pathophysiology of Type 2 diabetes. Diabetologia 46(1): 3-19.

9. Lowell BB, Shulman GI (2005) Mitochondrial dysfunction and type 2 diabetes. Science 307(5708): 384-387.

10. Bozzini C, Girelli D, Olivieri O, Martinelli N, Bassi A, et al. (2005) Prevalence of body iron excess in the metabolic syndrome. Diabetes Care 28(8): 2061-2063.

11. Gonzalez AS, Guerrero DB, Soto MB, Díaz SP, Martinez Olmos M, et al (2006) Metabolic syndrome, insulin resistance and the inflammation markers C-reactive protein and ferritin. Eur J Clin Nutr 60(6): 802-809.

12. Chang JS, Lin SM, Huang TC, Chao JC, Chen YC, et al. (2013) Serum ferritin and risk of the metabolic syndrome: a population-based study. Asia Pac J Clin Nutr 22(3): 400-407.

13. Jehn M, Clark JM, Guallar E (2004) Serum ferritin and risk of the metabolic syndrome in U.S. adults. Diabetes care 27(10): 2422-2428.

14. Iwasaki T, Nakajima A, Yoneda M, Yamada Y, Mukasa K, et al. (2005) Serum ferritin is associated with visceral fat area and subcutaneous fat area. Diabetes care 28(10): 2486-2491.

15. Jiang R, Manson JE, Meigs JB, Ma J, Rifai N, et al. (2004) Body iron stores in relation to risk of type 2 diabetes in apparently healthy women. JAMA 291(6): 711-717.

16. Cossarizza A, Ferraresi R, Troiano L, Roat E, Gibellini L, et al. (2009) Simultaneous analysis of reactive oxygen species and reduced glutathione content in living cells by polychromatic flow cytometry. Nat Protoc 4(12): 1790-1797.

17. Farrugia G, Balzan R (2012) Oxidative stress and programmed cell death in yeast. Front Oncol 2: 64.

18. Valko M, Izakovic M, Mazur M, Rhodes CJ, Telser J (2004) Role of oxygen radicals in DNA damage and cancer incidence. Mol Cell Biochem 266(1-2): 37-56.

19. Turrens JF, Boveris A (1980) Generation of superoxide anion by the NADH dehydrogenase of bovine heart mitochondria. BiochemJ 191(2): 421-427. 


\section{Current Research in Diabetes \& Obesity Journal}

20. Sies H (1997) Oxidative stress: oxidants and antioxidants. Exp Physiol 82(2): 291-295

21. Narayanan D, Xi Q, Pfeffer LM, Jaggar JH (2010) Mitochondria control functional CaV1.2 expression in smooth muscle cells of cerebral arteries. Circ Res 107(5): 631-641.

22. Didion SP, Hathaway CA, Faraci FM (2001) Superoxide levels and function of cerebral blood vessels after inhibition of CuZn-SOD. Am J Physiol Heart Circ Physiol 281: H1697-H1703.

23. Niwa K, Haensel C, Ross ME, Iadecola C (2001) Cyclooxygenase-1 participates in selected vasodilator responses of the cerebral circulation. Circ Res 88(6): 600-608.

24. Kinugawa S, Huang H, Wang Z, Kaminski PM, Wolin MS, et al. (2005) A defect of neuronal nitric oxide synthase increases xanthine oxidase-derived superoxide anion and attenuates the control of myocardial oxygen consumption by nitric oxide derived from endothelial nitric oxide synthase. Circ Res 96(3): 355-362.

25. Landmesser U, Dikalov S, Price SR, McCann L, Fukai T, et al. (2003) Oxidation of tetrahydrobiopterin leads to uncoupling of endothelial cell nitric oxide synthase in hypertension. J Clin Invest 111(8): 1201-1209.

26. Dikalova AE, Góngora MC, Harrison DG, Lambeth JD, Dikalov S, et al. (2010) Upregulation of Nox1 in vascular smooth muscle leads to impaired endothelium-dependent relaxation via eNOS uncoupling. Am Physiol Heart CircPhysiol 299(3): H673-H679.

27. Santhanam AV, d'Uscio LV, Smith LA, Katusic ZS (2012) Uncoupling of eNOS causes superoxide anion production and impairs NO signaling in the cerebral microvessels of hph-1 mice. J Neurochem 122(6): 1211 1218.

28. Drummond GR, Selemidis S, Griendling KK, Sobey CG (2011) Combating oxidative stress in vascular disease: NADPH oxidases as therapeutic targets. Nat Rev Drug Discov 10(6): 453-471.

29. Bhattacharyya S, Ghosh J, Sil PC (2012) Iron induces hepatocytes death via MAPK activation and mitochondria-dependent apoptotic pathway: beneficial role of glycine. Free Radic Res 46(10): 1296-1307.

30. Kayankarnna W, Thessomboon D, Niyomtam S, Pingmuangkaew P, Nunthawarasilp P, et al. (2013) Elevated cadmium exposure associated with oxidative stress and oxidative DNA damage in population of cadmium-contaminated area. Inter J Toxicol Phar Res 5: 102-108.

31. Pal PB, Pal S, Das J, Sil PC (2012) Modulation of mercury-induced mitochondria-dependent apoptosis by glycine in hepatocytes. Amino Acids 42(5): 1669-1683.

32. Pal PB, Sinha K, Sil PC (2013) Mangiferin, a natural xanthone, protects murine liver in $\mathrm{Pb}(\mathrm{II})$ induced hepatic damage and cell death via MAP kinase, NF- $\kappa$ B and mitochondria dependent pathways. PLoS One 8(2) e56894

33. Jia L, Liu Z, Sun L, Miller SS, Ames BN, et al. (2007) Acrolein, a toxicant in cigarette smoke, causes oxidative damage and mitochondrial dysfunction in RPE cells: protection by (R)-alpha-lipoic acid. Invest Ophthalmol Vis Sci 48(1): 339-348.

34. Roy A, Sil PC (2012) Tertiary butyl hydroperoxide induced oxidative damage in mice erythrocytes: Protection by taurine. Pathophysiology 19(2): 137-148

35. Bhattacharya S, Chatterjee S, Manna P, Das J, Ghosh J, et al. (2011) Prophylactic role of D-Saccharic acid-1,4-lactone in tertiary butyl hydroperoxide induced cytotoxicity and cell death of murine hepatocytes via mitochondria-dependent pathways. J Biochem Mol Toxicol 25(6) 341-354.

36. Ghosh A, Mandal AK, Sarkar S, Das N (2011) Hepatoprotective and neuroprotective activity of liposomal quercetin in combating chronic arsenic induced oxidative damage in liver and brain of rats. Drug Deliv 18(6): 451-459.
37. Sarkar MK, Sil PC (2010) Prevention of tertiary butyl hydroperoxide induced oxidative impairment and cell death by a novel antioxidant protein molecule isolated from the herb, Phyllanthusniruri. Toxicol In Vitro 24(6): 1711-1719.

38. Gutteridge JM (1995) Lipid peroxidation and antioxidants as biomarkers of tissue damage. Clin Chem 41(12 Pt 2): 1819-1828.

39. Halliwell B, Gutteridge JMC (1990) Role of free radicals and catalytic metal ions in human disease: an overview. Meth Enzymol 186: 1- 85.

40. Liuzzi JP, Aydemir F, Nam H, Knutson MD, Cousins RJ (2006) Zip14 (Slc39a14) mediates non-transferrin-bound iron uptake into cells. Proc Natl AcadSci USA 103(37): 13612-13617.

41. Mackenzie B, Ujwal ML, Chang MH, Romero MF, Hediger MA (2006) Divalent metal-ion transporter DMT1 mediates both $\mathrm{H}+$-coupled Fe2+ transport and uncoupled fluxes. Pflugers Arch 451: 544-558.

42. Beguin Y (2003) Soluble transferrin receptor for the evaluation of erythropoiesis and iron status. Clin Chim Acta 329(1-2): 9-22.

43. D’Alessio F, Hentze MW, Muckenthaler MU (2012) The hemochromatosis proteins HFE, TfR2, and HJV form a membrane-associated protein complex for hepcidin regulation. J Hepatol 57(5): 1052-1060.

44. Andriopoulos B, Corradini E, Xia Y, Faasse SA, Chen S, et al. (2009) BMP6 is a key endogenous regulator of hepcidin expression and iron metabolism. Nat Genet 41(4): 482-487.

45. Meynard D, Kautz L, Darnaud V, Canonne Hergaux F, Coppin H, et al (2009) Lack of the bone morphogenetic protein BMP6 induces massive iron overload. Nat Genet 41(4): 478-481.

46. Wang RH, Li C, Xu X, Zheng Y, Xiao C, et al. (2005) A role of SMAD4 in iron metabolism through the positive regulation of hepcidin expression. Cell Metab 2(6): 399-409.

47. Nemeth E, Tuttle MS, Powelson J, Vaughn MB, Donovan A, et al. (2004) Hepcidin regulates cellular iron efflux by binding to ferroportin and inducing its internalization. Science 306(5704): 2090-2093.

48. Mastrogiannaki M, Matak P, Keith B, Simon MC, Vaulont S, et al. (2009) HIF-2alpha, but not HIF-1alpha, promotes iron absorption in mice. J Clin Invest 119(5): 1159-1166.

49. Shah YM, Matsubara T, Ito S, Yim SH, Gonzalez FJ (2009) Intestinal hypoxia-inducible transcription factors are essential for iron absorption following iron deficiency. Cell Metab 9(2): 152-164.

50. Shayeghi M, Latunde Dada GO, Oakhill JS, Laftah AH, Takeuchi K, et al (2005) Identification of an intestinal heme transporter. Cell 122(5): 789-801.

51. Nelson R, Chawla M, Connolly P, LaPorte J (1978) Ferritin as an index of bone marrow iron stores. South Med J 71(12): 1482-1484.

52. Fleming DJ, Tucker KL, Jacques PF, Dallal GE, Wilson PW, et al. (2002) Dietary factors associated with the risk of high iron stores in the elderly Framingham Heart Study cohort. Am J Clin Nutr 76(6): 1375-1384.

53. Ganz T (2012) Macrophages and systemic iron homeostasis. J Innate Immun 4(5-6): 446-453.

54. Kohyama M, Ise W, Edelson BT, Wilker PR, Hildner K, et al. (2009) Role for Spi-C in the development of red pulp macrophages and splenic iron homeostasis. Nature 457(7227): 318-321.

55. Shoden A, Sturgeon P (1962) Iron storage, IV. Cellular distribution of excess liver iron. Am J Pathol 40: 671-683.

56. Corhay JL, Weber G, Bury T, Mariz S, Roelandts I, et al. (1992) Iron content in human alveolar macrophages. Eur Respir J 5(7): 804-809.

57. Ganz T, Nemeth E (2009) Iron sequestration and anemia of inflammation. Semin Hematol 46(4): 387-393. 


\section{Current Research in Diabetes \& Obesity Journal}

58. Hotamisligil GS (2006) Inflammation and metabolic disorders. Nature 444(7121): 860-867.

59. Jiang R, Ma J, Ascherio A, Stampfer MJ, Willett WC, et al. (2004) Dietary iron intake and blood donations in relation to risk of type 2 diabetes in men: a prospective cohort study. Am J ClinNutr 79(1): 70 -75.

60. Fernandez Real JM, Lopez Bermejo A, Ricart W (2005) Iron stores, blood donation, and insulin sensitivity and secretion. Clin Chem 51(7): 1201-1205

61. Cooksey RC, Jouihan HA, Ajioka RS, Hazel MW, Jones DL, et al. (2004) Oxidative stress, beta-cell apoptosis, and decreased insulin secretory capacity in mouse models of hemochromatosis. Endocrinology 145(11): 5305-5312.

62. Tiedge M, Lortz S, Drinkgern J, Lenzen S (1997) Relation between antioxidant enzyme gene expression and antioxidative defense status of insulin-producing cells. Diabetes 46(11): 1733-1742.

63. Andrews NC (1999) The iron transporter DMT 1. Int J Biochem Cell Biol 31(10): 991-994.

64. Sengsuk C, Tangvarasittichai O, Chantanaskulwong P, Pimanprom A Wantaneeyawong S, et al. (2014) Association of iron overload with oxidative stress, hepatic damage and dyslipidemia in transfusion-dependent $\beta$-thalassemia/HbE patients. Ind J Clin Biochem 29(3): 298-305.

65. Cooke MS, Evans MD, Dizdaroglu M, Lunec J (2003) Oxidative DNA damage: mechanisms, mutation, and disease. FASEB J 17(10): 11951214.

66. Evans JL, Goldfine ID, Maddux BA, Grodsky GM (2003) Are oxidative stress-activated signaling pathways mediators of insulin resistance and $\beta$-cell dysfunction? Diabetes 52(1): 1-8.

67. Shah S, Iqbal M, Karam J, Salifu M, Mc Farlane SI (2007) Oxidative stress, glucose metabolism, and the prevention of type 2 diabetes: pathophysiological insights. Antioxid Redox Signal 9(7): 911-929.

68. McClain DA, Abraham D, Rogers J, Brady R, Gault P, et al. (2006) High prevalence of abnormal glucose homeostasis secondary to decreased insulin secretion in individuals with hereditary haemochromatosis. Diabetologia 49(7): 1661-1669.

69. Dandona P, Hussain MA, Varghese Z, Politis D, Flynn DM, et al. (1983) Insulin resistance and iron overload. Ann Clin Biochem 20 Pt 2: 77-79.

70. Scott MD, van den Berg JJ, Repka T, Rouyer Fessard P, Hebbel RP, et al. (1993) Effect of excess alpha-hemoglobin chains on cellular and membrane oxidation in model beta-thalassemic erythrocytes. J Clin Invest 91(4): 1706-1712.

71. Rund D, Rachmilewitz E (2005) Beta-thalassemia. N Engl J Med 353(11): 1135-1146.

72. Torres FA, Bonduel M, Sciuccati G, delPozo A, Roldán A, et al. (2002) Beta thalassemia major in Argentina. Medicina (B Aires) 62(2): 124134

73. Khalifa AS, Salem M, Mounir E, El Tawil MM, El Sawy M, et al. (2004) Abnormal glucose tolerance in Egyptian beta-thalassemic patients: possible association with genotyping. Pediatr Diabetes 5(3): 126-132.

74. Cario H, Holl RW, Debatin KM, Kohne E (2003) Insulin sensitivity and beta-cell secretion in thalassaemia major with secondary haemochromatosis: assessment by oral glucose tolerance test. Eur J Pediatr 162(3): 139-146.

75. Chern JPS, Lin KH, Lu MY, Lin DT, Lin KS, et al. (2001) Abnormal glucose tolerance in transfusion-dependent $\beta$-thalassemic patients. Diabetes Care 24(5): 850-854.

76. Papanikolaou G, Pantopoulos K (2005) Iron metabolism and toxicity. Toxicol Appl Pharmacol 202(2): 199-211.
77. Cavallo Perin P, Pacini G, Cerutti F, Bessone A, Condo C, et al. (1995) Insulin resistance and hyperinsulinemia in homozygous beta-thalassemia. Metabolism 44(3): 281-286.

78. Brittenham GM, Griffith PM, Nienhuis AW, McLaren CE, Young NS, et al. (1994) Efficacy of deferoxamine in preventing complications of iron overload in patients with thalassemia major. N Engl J Med 331(9): $567-$ 573.

79. Platis O, Anagnostopoulos G, Farmaki K, Posantzis M, Gotsis E, et al (2004) Glucose metabolism disorders improvement in patients with thalassaemia major after 24-36 months of intensive chelation therapy. Pediatr Endocrinol Rev 2 (Suppl 2): 279-281.

80. Tangvarasittichai S, Pimanprom A, Choowet A, Tangvarasittichai 0 (2013) Association of iron overload and oxidative stress with insulin resistance in transfusion-dependent $\beta$-thalassemia major and $\beta$-thalassemia/HbE patients. Clin Lab 59(7-8): 861-868.

81. Loebstein R, Lehotay DC, Luo X, Bartfay W, Tyler B, et al. (1998) Diabetic nephropathy in hypertransfused patients with $\beta$-thalassemia: the role of oxidative stress. Diabetes Care 21(8): 1306-1309.

82. DeMaeyer E, Adiels Tegman M (1985) The prevalence of anaemia in the world. World Health Stat Q 38(3): 302-316.

83. Rockey DC, Cello JP (1993) Evaluation of the gastrointestinal tract in patients with iron deficiency anemia. N Engl J Med 329(23): 16911695.

84. Verloop MC, Vuylsteke J, Drogendijk AC (1960) On a patient with sideroblastic anemia and hemochromatosis. Sci Prog 90: 1213-1214.

85. Diez Ewald M, Layrisse M (1968) Mechanisms of hemolysis in iron deficiency anemia. Further studies. Blood 32(6): 884-894.

86. Huser HJ, Rieber EE, Berman AR (1967) Experimental evidence of excess hemolysis in the course of chronic iron deficiency anemia. J Lab Clin Med 69(3): 405-414.

87. Card RT, Weintraub LR (1971) Metabolic abnormalities of erythrocytes in severe iron deficiency. Blood 37(6): 725-732.

88. Rodvien R, Gillum A, Weintraub LR (1974) Decreased glutathione peroxidase activity secondary to severe iron deficiency: a possible mechanism responsible for the shortened life span of the iron-deficient red cell. Blood 43(2): 281-289.

89. Kempe DS, Lang PA, Duranton C, Akel A, Lang KS, et al. (2006) Enhanced programmed cell death of iron-deficient erythrocytes. FASEB J 20(2): 368-370.

90. Yip R, Mohandas N, Clark MR, Jain S, Shohet SB, et al. (1983) Red cell membrane stiffness in iron deficiency. Blood 62(1): 99-106.

91. Tillmann W, Schroter W (1980) Deformability of erythrocytes in iron deficiency anemia. Blut 40(3): 179-186.

92. Vaya A, Simo M, Santaolaria M, Todoli J, Aznar J (2005) Red blood cell deformability in iron deficiency anaemia. Clin Hemorheol Microcirc 33(1): $75-80$

93. Lang F, Lang KS, Lang PA, Huber SM, Wieder T (2006) Mechanisms and significance of eryptosis. Antioxid Redox Signal 8(7-8): 1183-1192.

94. Pfafferott C, Meiselman HJ, Hochstein P (1982) The effect of malonyldialdehyde on erythrocyte deformability. Blood 59(1): 12-15.

95. Damonte G, Guida L, Sdraffa A, Benatti U, Melloni E, et al. (1992) Mechanisms of perturbation of erythrocyte calcium homeostasis in favism. Cell Calcium 13(10): 649-658.

96. Christy AL, Manjrekar PA, Babu RP, Hegde A, Rukmini MS (2014) Influence of iron deficiency anemia on hemoglobin A1C levels in diabetic individuals with controlled plasma glucose levels. Iran Biomed J 18(2): 88-93. 


\section{Current Research in Diabetes \& Obesity Journal}

97. Hashimoto K, Noguchi S, Morimoto Y, Hamada S, Wasada K, et al (2008) A1C but not serum glycated albumin is elevated in late pregnancy owing to iron deficiency. Diabetes Care 31(10): 1945-1948.

98. Koga M, Morita S, Saito H, Mukai M, Kasayama S (2007) Association of erythrocyte indices with glycated haemoglobin in pre-menopausal women. Diabet Med 24(8): 843-847.

99. Borel MJ, Beard JL, Farrell PA (1993) Hepatic glucose production and insulin sensitivity and responsiveness in iron-deficient anemic rats. Am J Physiol 264(3 Pt 1): E380-E390.

100. Davies KJ, Donovan CM, Refino CJ, Brooks GA, Packer L, et al. (1984) Distinguishing effects of anemia and muscle iron deficiency on exercise bioenergetics in the rat. Am J Physiol 246(6 Pt 1): E535-E543.

101. Farrell PA, Beard JL, Druckenmiller M (1988) Increased insulin sensitivity in iron-deficient rats. J Nutr 118(9): 1104-1109.

102. Davis MR, Rendina E, Peterson SK, Lucas EA, Smith BJ, et al. (2012) Enhanced expression of lipogenic genes may contribute to hyperglycemia and alterations in plasma lipids in response to dietary iron deficiency. Genes Nutr 7(3): 415-425.

103. Yamagishi H, Komabayashi T (2003) Alteration of glucose metabolism and increased fructosamine in iron-deficiency anemic rats. Nutr Res 23(11): 1547-1553.

104. Davis MR, Hester KK, Shawron KM, Lucas EA, Smith BJ, et al. (2012) Comparisons of the iron deficient metabolic response in rats fed either an AIN-76 or AIN-93 based diet. Nutr Metab (Lond) 9(1): 95.

105. Borel MJ, Smith SH, Brigham DE, Beard JL (1991) The impact of varying degrees of iron nutriture on several functional consequences of iron deficiency in rats. J Nutr 121(5): 729-736.

106. Brooks GA, Henderson SA, Dallman PR (1987) Increased glucose dependence in resting, iron-deficient rats. Am J Physiol 253(4 Pt 1): E461-E466.

107. Linderman JK, Brooks GA, Rodriguez RE, Dallman PR (1994) Maintenance of euglycemia is impaired in gluconeogenesis-inhibited iron-deficient rats at rest and during exercise. J Nutr 124(11): 21312138.

108. Jackson CD, Weis C, Miller BJ, James SJ (1997) Dietary nucleotides: effects on cell proliferation following partial hepatectomy in rats fed NIH-31, AIN-76A, or folate/methyl-deficient diets. J Nutr 127(5 Suppl): 834S-837S.

109. Saad MJ, Morais SL, Saad ST (1991) Reduced cortisol secretion in patients with iron deficiency. Ann Nutr Metab 35(2): 111-115.

110. Márquez Ibarra A, Huerta M, Villalpando Hernández S, Ríos Silva M, Díaz Reval MI, et al. (2016) The effects of dietary iron and capsaicin on hemoglobin, blood glucose, insulin tolerance, cholesterol, and triglycerides, in healthy and diabetic wistar rats. PLoS One 11 (4): e0152625.

111. Gaj S, Eijssen L, Mensink RP, Evelo CT (2008) Validating nutrient-related gene expression changes from microarrays using RT(2) PCR-arrays. Genes Nutr 3(3-4): 153-157.

112. Pie J, Kim Y, Kim IK, Seo SH, Lee SH, et al. (2010) Correlation between nutrition intake and gene expression profiles in children with asthma. Mol Cell Toxicol 6(3): 313-319.

113. Henderson SA, Dallman PR, Brooks GA (1986) Glucose turnover and oxidation are increased in the iron-deficient anemic rat. Am J Physiol 250(4 Pt 1): E414-E421.

114. Iynedjian PB (2009) Molecular physiology of mammalian glucokinase. Cell Mol Life Sci 66(1): 27-42.

115. Iynedjian PB, Marie S, Gjinovci A, Genin B, Deng SP, et al. (1995) Glucokinase and cytosolic phosphoenolpyruvate carboxykinase (GTP) in the human liver. Regulation of gene expression in cultured hepato- cytes. J Clin Invest 95(5): 1966-1973.

116. Hagiwara A, Cornu M, Cybulski N, Polak P, Betz C, et al. (2012) Hepatic mTORC2 activates glycolysis and lipogenesis through Akt, glucokinase, and SREBP1c. Cell Metab 15(5): 725-738.

117. Shimomura I, Matsuda M, Hammer RE, Bashmakov Y, Brown MS, et al. (2000) Decreased IRS-2 and increased SREBP-1c lead to mixed insulin resistance and sensitivity in livers of lipodystrophic and ob/ ob mice. Mol Cell 6(1): 77-86.

118. Accili D, Arden KC (2004) FoxOs at the crossroads of cellular metabolism, differentiation, and transformation. Cell 117(4): 421-426.

119. Horton JD, Goldstein JL, Brown MS (2002) SREBPs: transcriptional mediators of lipid homeostasis. Cold Spring Harb Symp Quant Biol 67: 491-498.

120. Li S, Brown MS, Goldstein JL (2010) Bifurcation of insulin signaling pathway in rat liver: mTORC1 required for stimulation of lipogenesis, but not inhibition of gluconeogenesis. Proc Natl Acad Sci USA 107(8): 3441-3446.

121. Medinsky MA, Popp JA, Hamm TE, Dent JG (1982) Development of hepatic lesions in male Fischer-344 rats fed AIN-76A purified diet. Toxicol Appl Pharmacol 62(1): 111-120.

122. Stangl GI, Kirchgessner M (1998) Different degrees of moderate iron deficiency modulate lipid metabolism of rats. Lipids 33(9): 889-895.

123. Brooks AP, Metcalfe J, Day JL, Edwards MS (1980) Iron deficiency and glycosylated haemoglobin A. Lancet 2(8186): 141.

124. Kim C, Bullard KM, Herman WH, Beckles GL (2010) Association between iron deficiency and $\mathrm{A} 1 \mathrm{C}$ levels among adults without diabetes in the National Health and Nutrition Examination Survey, 19992006. Diabetes Care 33(4): 780-785.

125. Ozdemir A, Sevinç C, Selamet U, Kamaci B, Atalay S (2007) Age-and body mass index-dependent relationship between correction of iron deficiency anemia and insulin resistance in non-diabetic premenopausal women. Ann Saudi Med 27(5): 356-361.

126. Kim C, Bullard KM, Herman WH, Beckles GL (2010) Association between iron deficiency and A1C levels among adults without diabetes in the National Health and Nutrition Examination Survey, 19992006. Diabetes Care 33(4): 780-785.

127. Gram Hansen P, Eriksen J, Mourits Andersen T, Olesen L (1990) Glycosylated haemoglobin (HbA1c) in iron- and Vitamin B12 deficiency. J Intern Med 227(2): 133-136.

128. Rafat D, Rabbani TK, Ahmad J, Ansari MA (2012) Influence of iron metabolism indices on $\mathrm{HbA1c}$ in non-diabetic pregnant women with and without iron-deficiency anemia: effect of iron supplementation. Diabetes Metab Syndr 6(2): 102-105.

129. Bhardwaj K, Sharma SK, Rajpa N, Sachdev A (2016) The effect of iron deficiency anaemia on haemoglobin A1c levels. Ann Clin Lab Res 4: $1-7$.

130. Ng JM, Cooke M, Bhandari S, Atkin SL, Kilpatrick ES (2010) The effect of iron and erythropoietin treatment on the A1C of patients with diabetes and chronic kidney disease. Diabetes Care 33(11): 2310-2313.

131. Davis RE, McCann VJ, Nicol DJ (1983) Influence of iron-deficiency anaemia on the glycosylated haemoglobin level in a patient with diabetes mellitus. Med J Aust 1(1): 40-41.

132. Keane WF, Lyle PA (2003) Recent advances in management of type 2 diabetes and nephropathy: lessons from the RENAAL study. Am J Kidney Dis 41(3 Suppl 1): S22- S25.

133. Ueda H, Ishimura E, Shoji T, Emoto M, Morioka T, et al. (2003) Factors affecting progression of renal failures in patients with type 2 diabetes. Diabetes Care 26(5): 1530-1534. 


\section{Current Research in Diabetes \& Obesity Journal}

134. Grune T, Sommerburg 0, Siems WG (2000) Oxidative stress in anemia. Clin Nephrol 53(Suppl 1): S18-S22.

135. Fine LG, Bandyopadhay D, Norman JT (2000) Is there a common mechanism for the progression of different types of renal diseases other than proteinuria? Towards the unifying theme of chronic hypoxia. Kidney Int 57(Suppl 75): S22-S26.

136. Meroño T, Dauteuille C, Tetzlaff W, Martín M, Botta E, et al. (2017) Oxidative stress, HDL functionality and effects of intravenous iron administration in women with iron deficiency anemia. Clin Nutr 36(2): 552-558.

137. Yang S, Chen XY, Xu XP (2015) The Relationship between lipoprotein-associated phospholipase $\mathrm{A}(2)$, cholesteryl ester transfer protein and lipid profile and risk of atherosclerosis in women with iron deficiency anaemia. Clin Lab 61: 1463-1469.

138. Angelousi A, Larger E (2015) Anaemia, a common but often unrecognized risk in diabetic patients: a review. Diabetes Metab 41(1) 18-27

139. Fava S, Azzopardi J, Ellard S, Hattersley AT (2001) ACE gene polymorphism as a prognostic indicator in patients with type 2 diabetes and established renal disease. Diabetes Care 24(12): 2115-2120.

140. Jha V, Garcia Garcia G, Iseki K, Li Z, Naicker S, et al. (2013) Chronic kidney disease: global dimension and perspectives. Lancet 382(9888) 260-272.

This work is licensed under Creative Commons Attribution 4.0 Licens

DOI: 10.19080/CRDOJ.2018.07.555719
141. Barbieri J, Fontela PC, Winkelmann ER, Zimmermann CEP, Sandri YP, et al. (2015) Anemia in patients with type 2 diabetes mellitus. Anemia 2015: 354737.

142. Weiss G, Goodnough LT (2005) Anemia of chronic disease. N Engl J Med 352: 1011-1023.

143. Kashyap AS, Kashyap S (2000) Haemolyticanaemia due to metformin Postgrad Med J 76(892): 125-126.

144. Garratty G (2009) Drug-induced immune hemolytic anemia. Hematology Am Soc Hematol Educ Program 2009: 73-79.

145. Packer CD, Hornick TR, Augustine SA (2008) Fatal hemolytic anemia associated with metformin: a case report. J Med Case Rep 2: 300.

146. Lin KD, Lin JD, Juang JH (1998) Metformin-induced hemolysis with jaundice. N Engl J Med 339(25): 1860-1861.

147. Kirkiz S, Yarali N, ArmanBilir O, Tunc B (2014) Metformin-induced hemolytic anemia. Med Princ Pract 23(2): 183-185.

148. Meir A, Kleinman Y, Rund D, DA'AS N (2003) Metformin-induced hemolytic anemia in a patient with glucose-6-phosphate dehydrogenase deficiency. Diabetes Care 26(3): 956-957.

149. Zanella A, Barcellini W (2014) Treatment of autoimmune hemolytic anemias. Haematologica 99(10): 1547-1554.

\section{Your next submission with Juniper Publishers} will reach you the below assets

- Quality Editorial service

- Swift Peer Review

- Reprints availability

- E-prints Service

- Manuscript Podcast for convenient understanding

- Global attainment for your research

- Manuscript accessibility in different formats

( Pdf, E-pub, Full Text, Audio)

- Unceasing customer service

Track the below URL for one-step submission

https://juniperpublishers.com/online-submission.php 